\title{
The Malian Lakes Region redefined: archaeological survey of the Gorbi Valley
}

Peter R. Coutros*

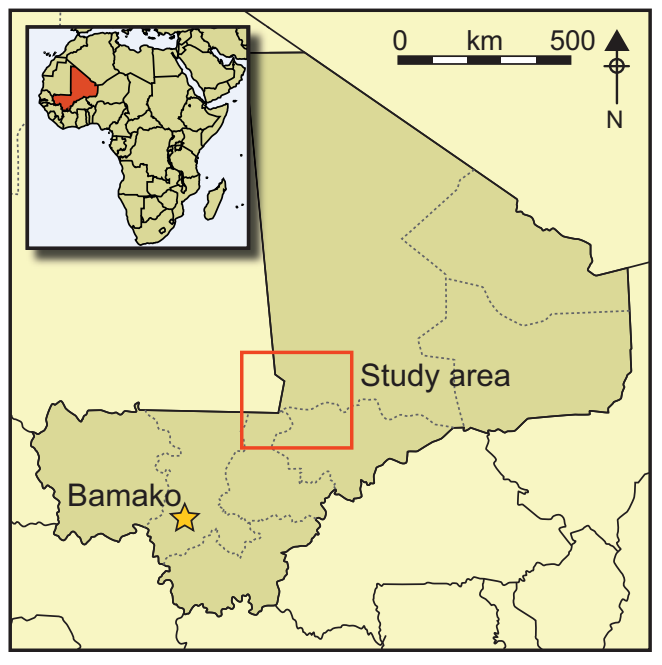

The Malian Lakes Region of West Africa has long been overlooked in favour of betterknown basins of the Niger River. New archaeological survey of this region, however, shows a history far more complex than had previously been thought, with settlement mounds and multiple phases of migration and eventual abandonment in a landscape of shifting power structures between the first millennium $B C$ and second millennium $A D$. With the establishment of a relative chronology, the archaeology of this region now holds great potential for a better understanding of the broader cultural history of the Ghana Empire.

Keywords: Mali, mid-Holocene, Ghana Empire, settlement mounds

\section{Introduction}

Situated along the Niger Bend, between the arid Saharan desert and the semi-arid Sudanian Savanna, the Malian Lakes Region (MLR) is one of the final expressions of the so-called 'Green Sahara' (Figure 1). This patchwork of lakes, ponds, marshes, rivers and streams is all that remains of a vast, lush ecosystem that once provided refuge for substantial Late Stone Age and Early Iron Age populations during the dramatic climate fluctuations of the Late Holocene (Coutros \& Douglas 2015). Nevertheless, archaeological investigations of the Western Sudan have generally neglected this region in favour of the more historically famous basins of the Middle Niger. Referred to mainly as a tumuli zone-a characterisation that is far from securely established-the MLR has been regarded as peripheral to major developments across the broader region (Desplagnes 1903; Fontes et al. 1985; McIntosh 1988). New evidence demonstrates, however, that throughout the period of the Ghana Empire, the MLR was densely populated, and doubtless played a crucial role in the historical development of the Western Sudan (Dembélé 1986; Raimbault \& Sanogo 1991).

* Department of Anthropology, Yale University, 10 Sachem Street, New Haven, CT 06511, USA (Email: peter.coutros@yale.edu) 


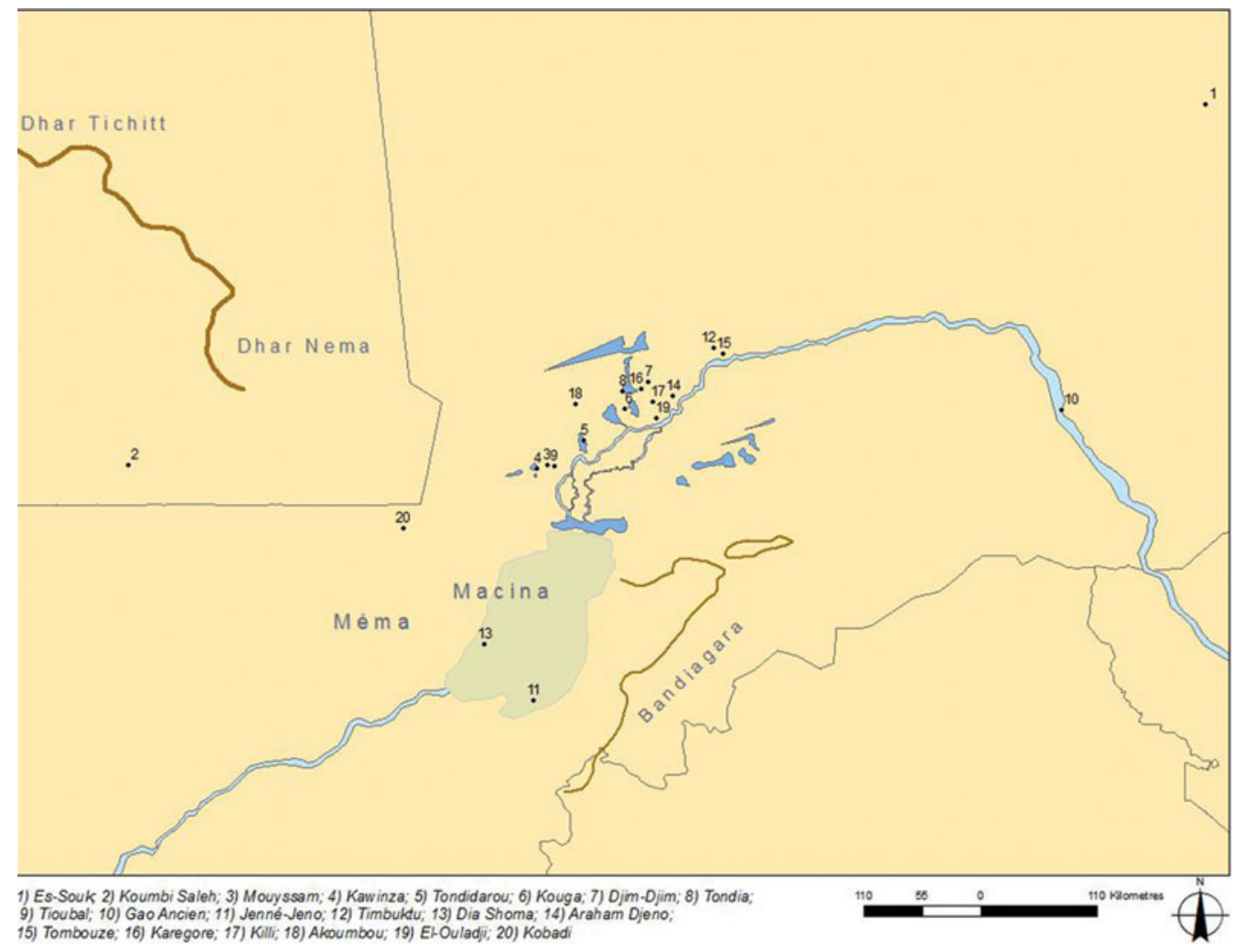

Figure 1. Map showing the Malian Lakes Region and all sites mentioned in the text in their geographic context.

The results of the Gorbi Valley survey bring to light new evidence from this significant, yet overlooked, region of West Africa.

\section{Archaeological setting}

The archaeological landscape of the MLR is uncommonly rich and diverse. Megaliths, ironworking sites, tumuli and occupation sites have all been documented throughout the region (Dembélé 1986; Raimbault \& Sanogo 1991). The anthropogenic mounds of the MLR differ greatly in their formation from those in nearby regions, with material accumulating extremely rapidly in relatively confined concentrations, leading to vertically exaggerated mounds. Mouyssam 2, for instance, accumulated a height of $9.6 \mathrm{~m}$ through the deposition of cultural material between AD 300 and 680 (Raimbault \& Sanogo 1991). Of the 56 sites where height has been recorded, 32 are over $10 \mathrm{~m}$ tall, yet few exceed $500 \mathrm{~m}$ in diameter-Arham-jeno is a notable exception, measuring over 100ha (McIntosh 1988: 191). Settlement patterns of the MLR resemble those of the Inland Niger Delta, and Dia in the Macina basin, with sites clustering in groups of up to ten, arranged as small mounds in orbit around one or two larger mounds (McIntosh 2000: 27). Dates taken from excavated contexts at Mouyssam 2 (AD 240/540-620/675), Kawinza (AD 950/715) and Touble 
(AD 340/540-1210/1295), span the first- and early second-millennium AD reign of the Ghana Empire (Raimbault \& Sanogo 1991).

Despite the abundance of such impressive sites, the MLR has received relatively little attention from researchers. The most active period of research occurred under the French colonial administration during the late nineteenth and early twentieth centuries. Excavations led by Lieutenant Louis Desplagnes between 1903 and 1908 (Killi and ElOualaji), and Raymond Mauny in 1954/1955 (Jim-jim and Tondia), focused on sites of the region in the belief that they were tumuli. Two campaigns of prospection, La Mission LereFaguibine in 1981-1983, and the Projet Inventaire des Sites Archaeologiques de Mali in 1984, however described wide diversity in the 222 identified sites (Dembélé 1986; Raimbault \& Sanogo 1991). Influenced by the earlier work by Desplagnes and Mauny, 15 of the sites were nevertheless classified as tumuli from the evidence of their elevated, steep slopes, as opposed to the larger settlement mounds with gradual slopes. Although this generalised classification has become widely accepted, it is uncertain how well 'l'hypothèse de grands tumulus funéraires' matches the archaeological reality (Dembélé \& Raimbault 1991: 249).

Major gaps in our understanding of the history of the MLR still exist. The abundance of habitation mounds, ironworking sites and megaliths throughout the first and early second millennium $\mathrm{AD}$ clearly demonstrates, however, that the region was a major player in antiquity.

\section{The Gorbi Valley}

Given the state of archaeological knowledge of the MLR, the study described here was exploratory in nature and focused on identifying site locations and distribution, as well as collecting preliminary information on ceramic assemblages (Coutros \& Douglas 2015: 250). In order to accomplish the stated objectives with the available resources, the survey area was limited to a $3 \times 3 \mathrm{~km}$ region on the eastern shore of Lake Fati, named the Gorbi Valley, bounded to the north and south by two large massifs (Figure 2). Designed as the first phase of a larger project, a three-part strategy was developed, including a remote-sensing analysis, ground-truthing campaign and systematic pedestrian survey, to inform a more thorough investigation.

The utility of aerial and satellite imagery for locating and mapping geomorphological features and archaeological phenomena in the arid and semi-arid regions of West Africa has been repeatedly demonstrated (Haskell et al. 1986; McIntosh \& McIntosh 1985; Jacobberger 1988; de Vries et al. 2005; Park 2012). The lack of thick vegetation and generally low topographic relief result in high site visibility. Following the success of the Tombouze study (Park 2012), co-directed by the present author, a similar methodology was adopted for the Gorbi Valley. Using ASTER and Landsat imagery, coordinates of potential sites were downloaded onto a portable GPS receiver to be verified by the ground-truthing campaign.

The team sampled each confirmed site, where a $1 \times 1 \mathrm{~m}$ square was randomly partitioned, and from which all rim sherds were collected. Rim sherds were isolated due to their advantages in defining attributes of ceramic assemblages for diachronic and comparative studies (McIntosh \& McIntosh 1985). Once sampled, the perimeter of each site was (C) Antiquity Publications Ltd, 2017 


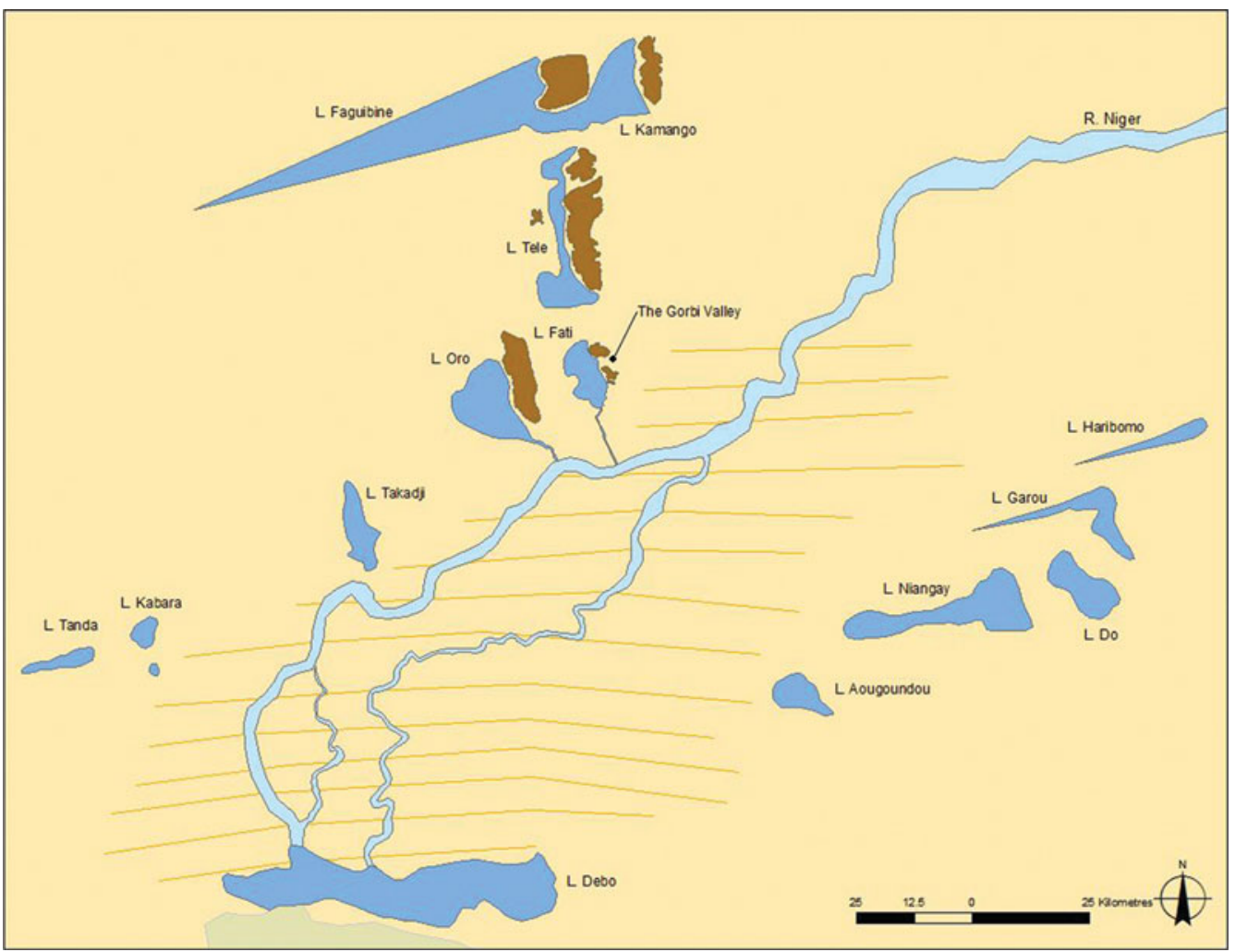

Figure 2. Map showing the location of the Gorbi Valley within the MLR. The brown areas indicate the sandstone massifs to the east of the lakes, and orange lines represent the major longitudinal dune formations created during the Pleistocene.

mapped so as to define their visible extents. Sites were numbered in the order in which they were encountered, using the prefix Fati (i.e. Fati1) after the adjacent lake.

In addition to collecting from known sites, a systematic survey was conducted to identify the distribution of sites not detected by the remote-sensing study. Transects were spaced at $100 \mathrm{~m}$ intervals with collection points every $100 \mathrm{~m}$. All artefacts within a $1 \times 1 \mathrm{~m}$ square established at each collection point were collected, regardless of type or size. Additionally, an unsystematic reconnaissance of the surrounding area was conducted in order to explore the immediate periphery of the valley.

\section{Results}

Typology of sites

In light of uncertainty regarding the distinction between habitation mounds and tumulus mounds, the research team did not adopt the site classifications developed by earlier projects. Instead, sites identified within the study area were subdivided into four categories according to their general forms: 1) Fati6 is unique in its size and in having multiple stone features; 2) Fati4, Fati5 and Fati7 are large, elevated mounds without visible stone features; 


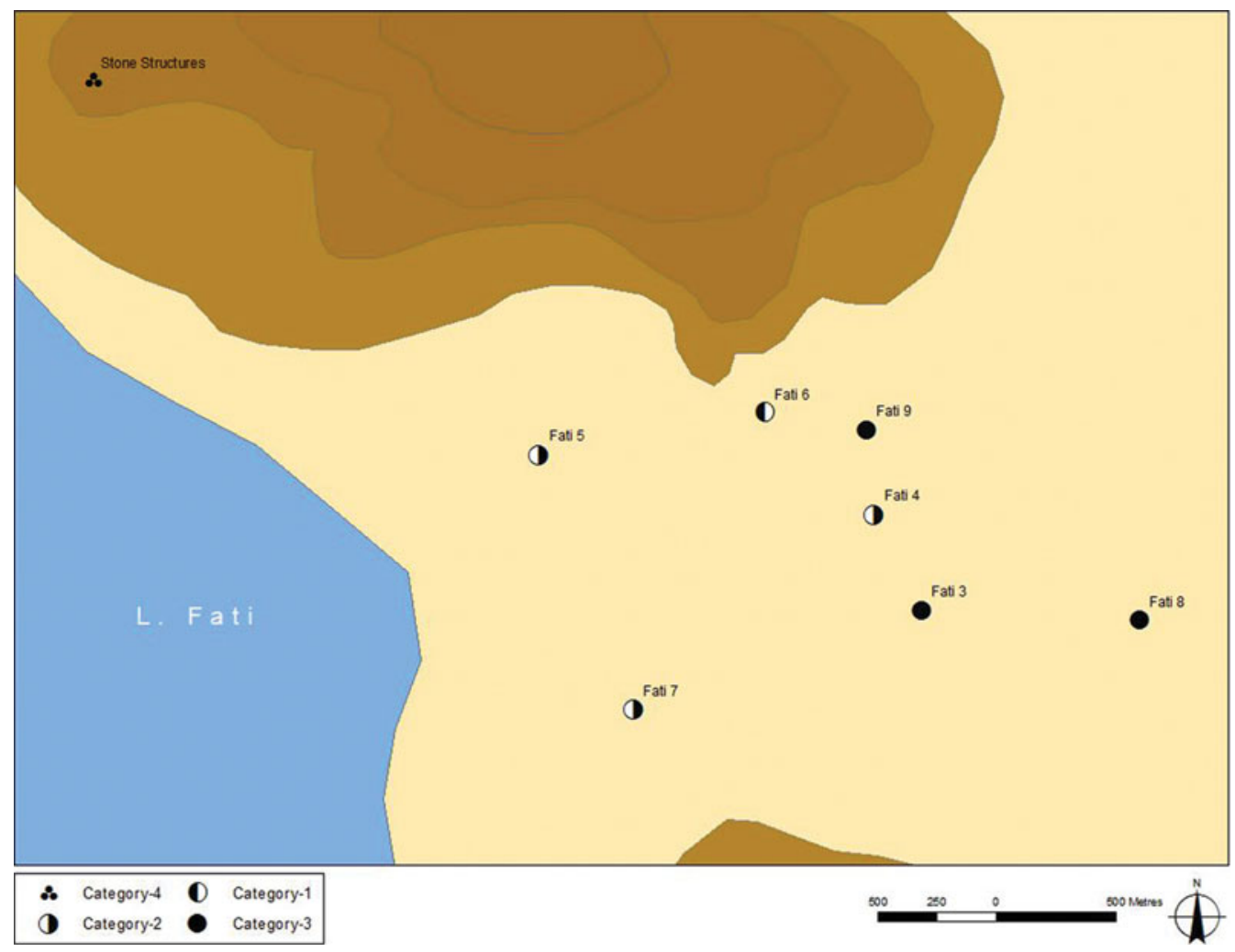

Figure 3. The distribution of sites within the Gorbi Valley.

3) Fati8 and Fati9 are sprawling pottery scatters; 4) other sites consisted of clusters of stone structures on the crest of the sandstone exposures (Figure 3).

\section{Category 1}

Due to its prominence and number of stone features, Fati6 is the sole site in this category. The site is comprised of a large, multi-component tell measuring approximately $18 \mathrm{~m}$ tall and 4 ha in surface area. The surface is covered in pottery fragments, loose stones and various exposed features. The stone features, constructed of dry-stone masonry, have been classified as either structures or complexes. Structures are here defined as physically independent, individual units, while complexes are multiple structures physically linked or constructed as directly associated units (Figures 4 \& 5). It must be noted, however, that modern stone collecting has dismantled many of these features, potentially isolating structures that may originally have been portions of larger complexes (Coutros 2015). In all, ten individual structures and two large complexes were identified and mapped (Figure 6). Both complexes and structures contain linear, circular and curvilinear elements, and range between $0.25 \mathrm{~m}$ and $1 \mathrm{~m}$ in height with an average wall width of $0.6 \mathrm{~m}$.

Complex 1 consisted of seven interconnected structures (Figure 4: C1). To the south and east, the complex is enclosed by a wall, leaving the only entrance to the west, (C) Antiquity Publications Ltd, 2017 
The Malian Lakes Region redefined

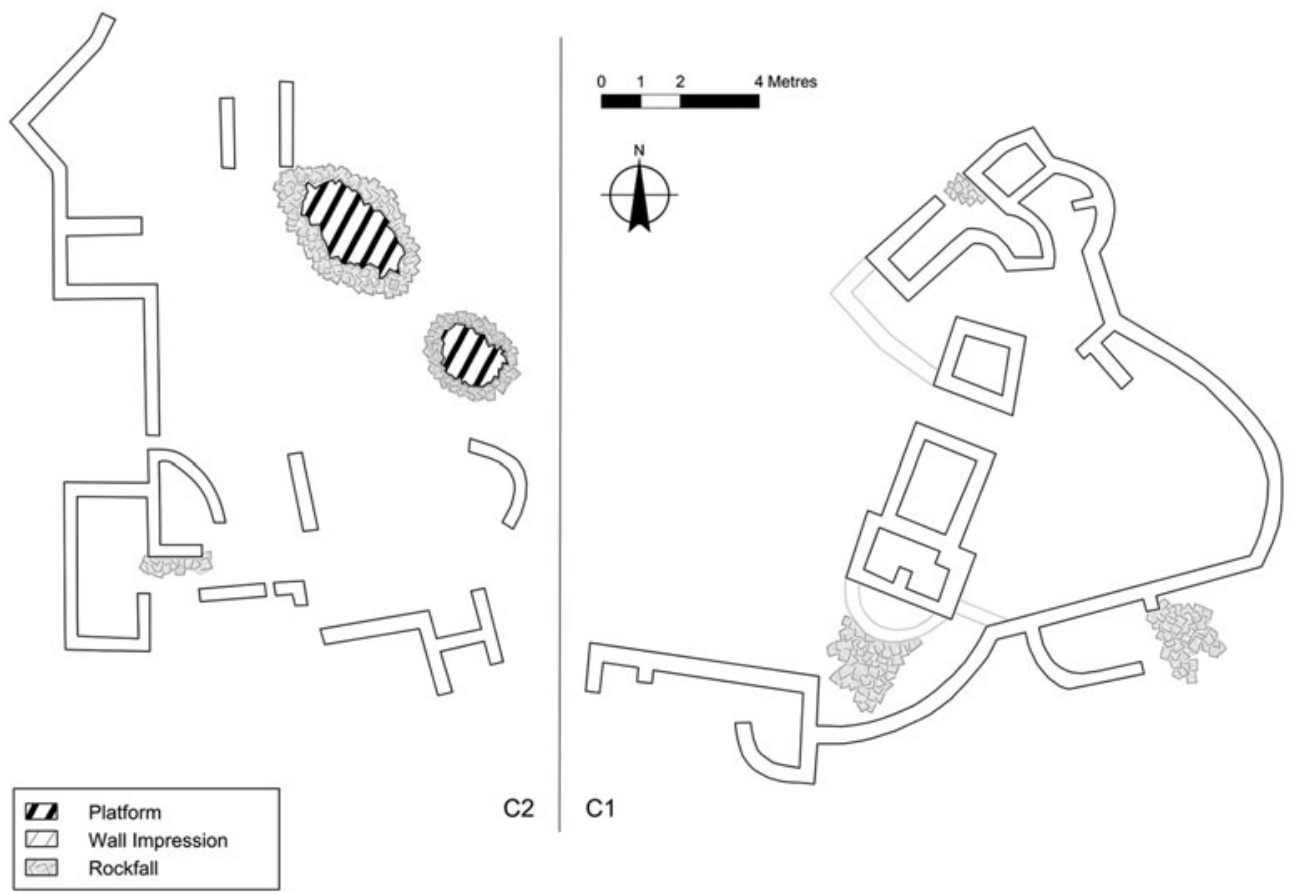

Figure 4. Complexes (labelled C1 and C2) found at Fati6 complexes.

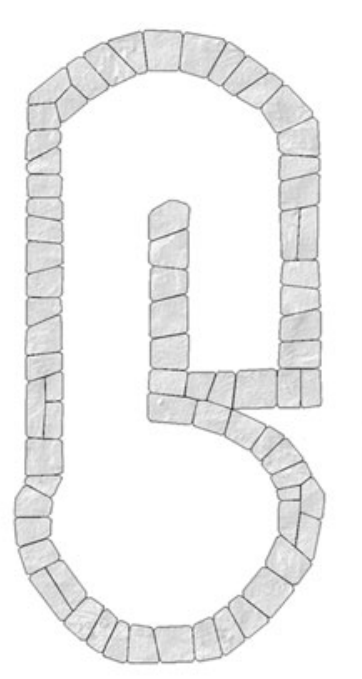

S1

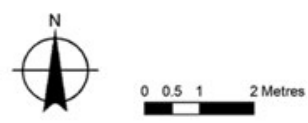

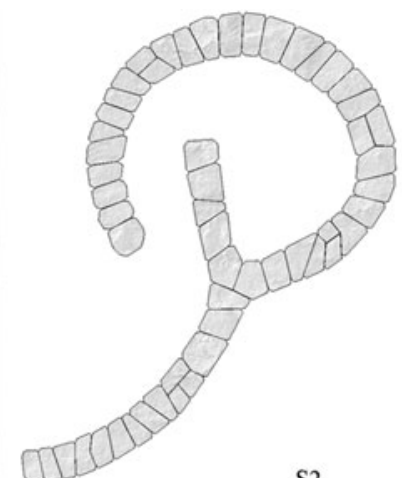

S2

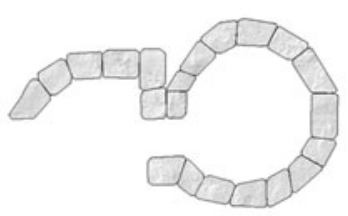

S5

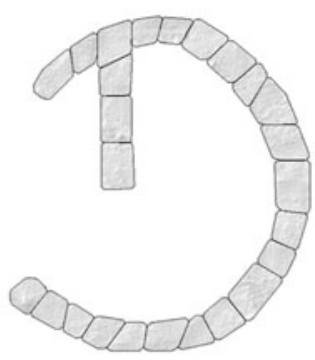

S4

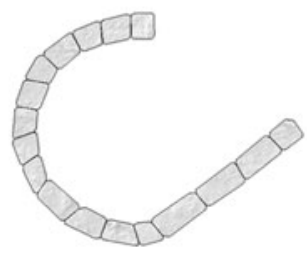

S6

Figure 5. Plan of the structures found at Fati6. The most well preserved were structures 1-6, labelled here S1-S6.

(C) Antiquity Publications Ltd, 2017 


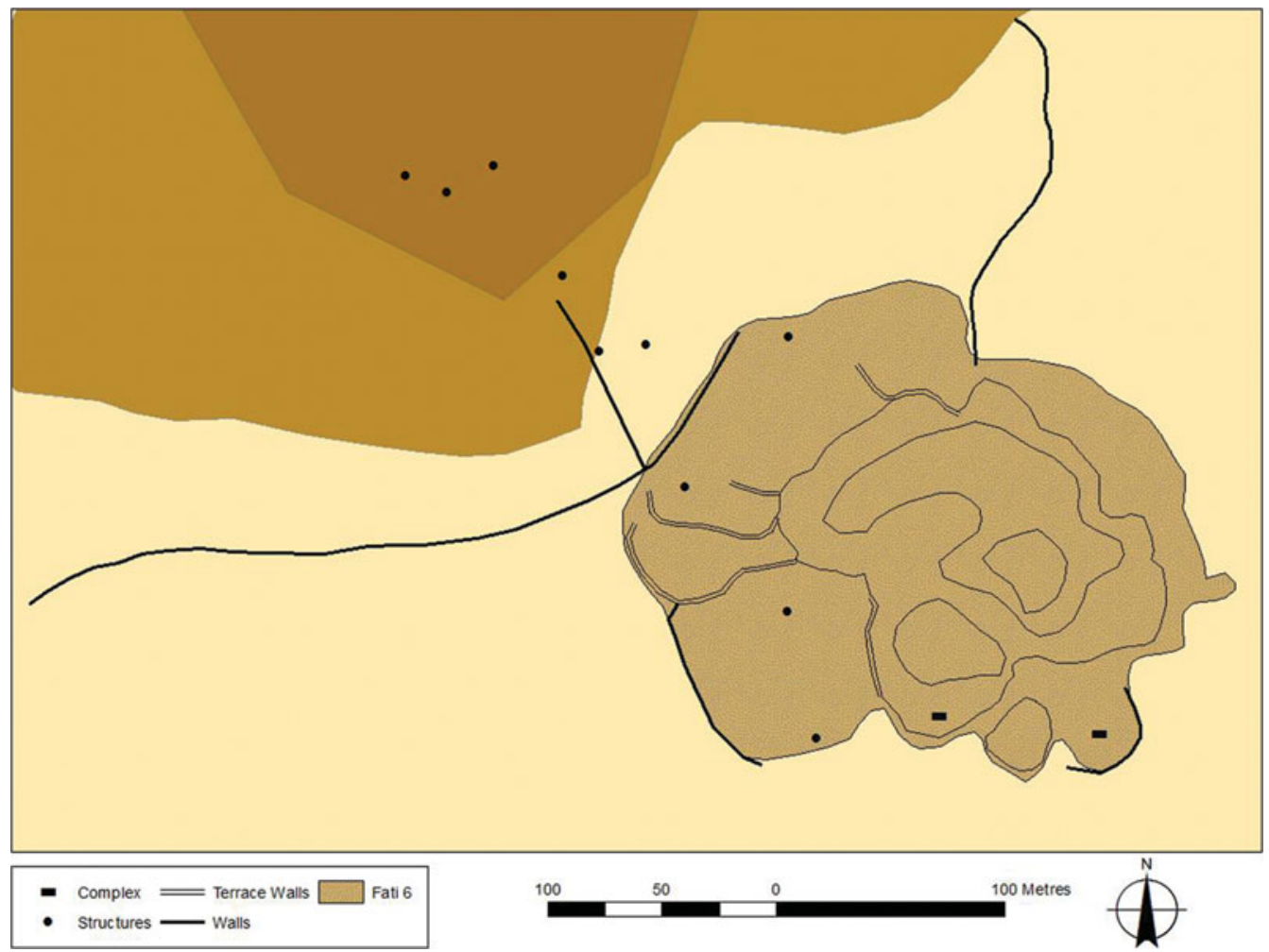

Figure 6. A site map of Fati6. The brown areas in the north-west represent the sandstone outcrop at the northern limit of the Gorbi Valley; the darker area represents the highest point of elevation.

between the two central structures. Complex 2 was less extensive, containing a seemingly irregular network of walls, one clearly distinguishable structure to the south-west and two platforms in the north-east quadrant, raised approximately $0.5 \mathrm{~m}$ above the ground floor, and surrounded by rock-fall (Figure 4: C2).

Several standing walls, independent of any structures, were also present at Fati6. Ranging between 1 and $3 \mathrm{~m}$ in height, these walls were constructed in a clear attempt to enclose the main central tell. To the north-east, an extensive wall stretches approximately $150 \mathrm{~m}$, in a north-south direction, from the north-west edge of the focus tell to the face of the northern massif. A second enclosing wall runs circuitously for approximately $150 \mathrm{~m}$ from the edge of the northern massif to the north-east perimeter of the focus tell. To the west, another wall extends $250 \mathrm{~m}$ in an east-west fashion away from the site, mirroring the rock-face and perpendicularly intersected by the $150 \mathrm{~m}$ long north-south wall. Within the bounds of these enclosing walls, a series of inner walls appear to have been built as a progression of terraces upon which several complexes and structures were constructed.

In-depth research into African walled constructions is lacking, but walls are containers, and as such may provide insight into their contents (Connah 2000: 36). The height of the outer walls—at some points exceeding $3 \mathrm{~m}$ —as well as their position surrounding the focus (C) Antiquity Publications Ltd, 2017 
tell, underscores their defensive nature. The precise function of the internal complexes or individual structures, however, proves more elusive. The position of these features within the enclosing walls may indicate their use as protected communal storage facilities or gathering points. Alternatively, these complexes may have been exclusive sectors, access to which was restricted to certain segments of the population. Future investigations should target these features in order to test these hypotheses.

\section{Category 2}

Since the earliest archaeological investigations in the MLR, the massive earthen mounds have been regarded as tumuli (Desplagnes 1903; Mauny 1961; Levtzion 1973; Martin \& Becker 1974; Descamps 1979; Raimbault \& Sanogo 1991). At El-Oualaji, Desplagnes identified what he believed was a vaulted wooden burial chamber, containing two individuals accompanied by stone beads, iron bracelets, weaponry and zoomorphic figurines. Similarly, at Killi, two individuals were uncovered in association with presumed grave goods. To Desplagnes and Mauny, these sites bore a striking resemblance to Al-Bakri's Description de l'Afrique Septentrionale, in which he describes the funeral rites of the Kings of the Ghana Empire (Levtzion \& Hopkins 1981: 80-81).

The past 65 years of archaeological investigations in West Africa have provided researchers with better frameworks from which to interpret sites, calling these original interpretations into question. The notion that these sites are tumuli is reliant on the recovery of human remains, but also the unique morphology of Category 2 sites. The confined and exaggerated mounds fostered the perception that they were 'monuments' constructed in a single phase. What is now clear, however, is that they resulted from the irregular erosion of multi-phase mud-brick structures (McIntosh 1974).

At Killi, Desplagnes excavated with no consideration for stratigraphy, uncovering 34 burials at varying depths (1907). Rather than indicating the contemporaneous inhumation of royal attendants or subsequent intrusive burials, as he suggested, they are probably evidence of an occupation spanning several phases. Burials at sites within or between habitation contexts are common in West Africa. At Kobadi, excavations showed that the habitation zone extended over both the cemetery and midden areas (MacDonald 1996: 433), while Bedaux et al. (2001: 845) found over 40 burials interspersed within domestic contexts at Dia Shoma from horizons III and IV alone.

The mixture of human remains, animal bones, ash, pottery and iron objects throughout the matrix of mounds, once believed to be grave goods and sacrificial fires, has since become diagnostic of occupation sites. In fact, the only three sites to be excavated with modern, scientific methods-Mouyssam 2, Kawinza and Toubel—have all been identified as habitation mounds (McIntosh 1988; Raimbault \& Sanogo 1991).

Throughout West Africa the practice of building large funerary mounds was common during the first millennium AD, with over 10000 identified in Senegal alone (Martin \& Becker 1974; Descamps 1979; McIntosh \& McIntosh 1993). Given this widespread tradition, it may be that particular sites in the MLR are indeed tumuli. At this point, however, there is little evidence to suggest that Category 2 sites are anything other than habitation mounds. 


\section{Category 3}

Category 3 sites include Fati8 and Fati9. Consisting of pottery scatters over wide, flat mounds of melted mud-brick, many of these have been neglected in favour of the more visible Category 2 sites. These low-relief sites are common throughout the broader region and resemble those of the Timbuktu region, particularly Tombouze 1 and 2 (Park 2012). Neither the function nor extent of Category 3 sites is immediately clear, they are, however, generally interpreted as habitation mounds, special activity sites or as a combination of both.

\section{Category 4}

The final category of sites is limited to the summits of the massif that delimit the study area. Their location means that these sites fell outside the main survey and were located during the informal reconnaissance phase. Organised in large compounds, they are composed of dozens of interconnected circular structures (Figure 7A). These compounds are constructed of dry-stone masonry, lack surface material and have left no immediate clues as to their use or period of occupation. A revision of satellite imagery revealed that these complexes exist throughout the massif that extends $74 \mathrm{~km}$ north to the eastern shores of Lake Faguibine (Figure 8).

B

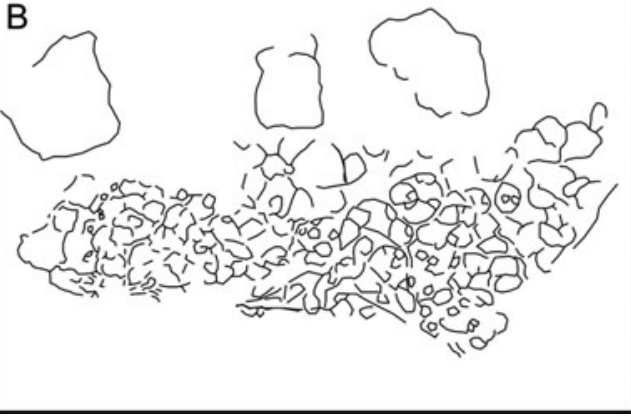

Figure 7. Schematic drawing showing the similarities between the (A) MLR Category 4 sites (currently unnamed), and (B) Dhar Tichitt sites, exemplified by Site 38 (after Holl 1985).
Looking to nearby regions for potential comparisons leads to the sandstone escarpment of the Dhar Tichitt region in southeast Mauritania. Here, Holl identified 43 similar compounds, including multiple dwelling units, hearths, storage facilities and livestock enclosures (Holl 1985). For example, Holl's Site 38 from Dhar Tichitt (Figure 7B) bears a striking resemblance to the first Category 4 site located (Figure 7A). During the first and second millennia BC, agro-pastoral communities flourished along the Dhar Tichitt around the permanent and semi-permanent water sources that formed in the Aouker/Hodh depression. Engaged in fishing, hunting, millet cultivation and husbandry of bovids and Ovis/Capra, these communities formed the earliest large-scale sedentary settlements west of the Nile (Munson 1971; MacDonald et al. 2003; Holl 2009).

(C) Antiquity Publications Ltd, 2017 


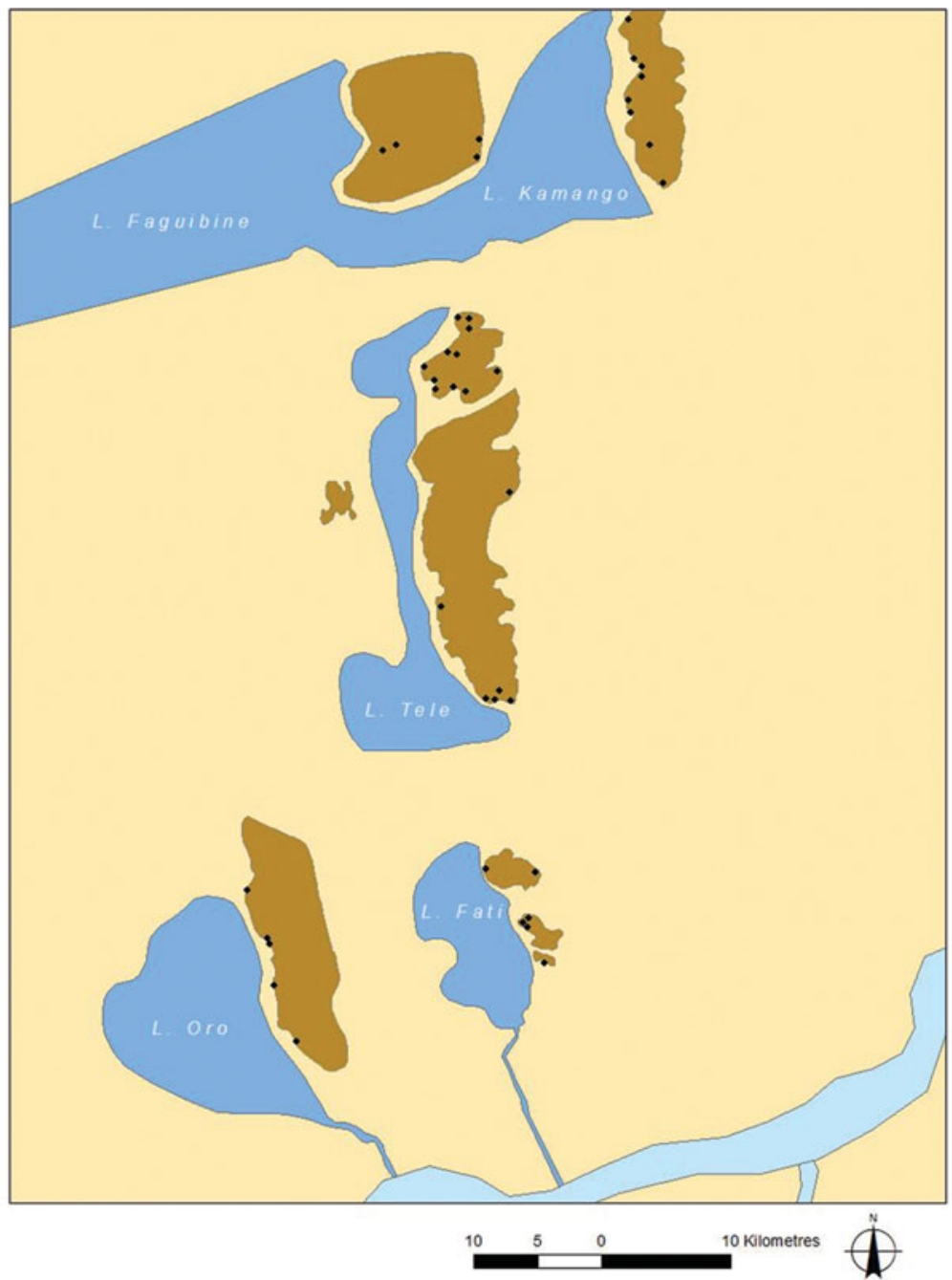

Figure 8. Map showing the distribution of Category 4 sites along the sandstone massifs.

By $300 \mathrm{BC}$, partially in response to the drying environment, populations began to move out of the Dhar Tichitt along the south-eastern Dhar Nema escarpment (MacDonald et al. 2003). The lack of substantial stone architecture and the relative increase in Late Tichitt sites in the Dhar Nema led MacDonald et al. to believe that the region may have served as a "place of passage" for migrating populations leaving the Dhar Tichitt (2009: 45). Where these populations finally settled, however, is unclear, although regions such as the Méma, Macina and MLR appear to be the most viable candidates. Connections with the Tichitt Tradition have long been established at the Méma and Macina sites of Kobadi and Dia Shoma (MacDonald 1994, 1996, 1999; Bedaux et al. 2001; MacDonald et al. 2003). As this was probably not a direct migration, other regions may provide additional insight into the process of this exodus. With its lakeside sandstone massifs, the MLR 
would have resembled the Dhar Tichitt, and may have attracted its former occupants. These architectural similarities may be superficial, resulting simply from the availability of materials, or, as is hypothesised here, it may represent a larger pattern of significant regional contact or migration.

\section{Material culture}

All artefacts collected, regardless of size, were counted and weighed. Some ceramic sherds were too small $(<20 \mathrm{~mm})$ to distinguish decorative patterns, and were included in the overall count and weight statistics, but not in those of decorative motifs. The only non-ceramic artefacts (three polished stone axes) recovered during the survey were "culturally undiagnostic", meaning, therefore, that ceramics provided the only useful data for diachronic and comparative studies (MacDonald et al. 2009: 11).

In total, 373 individual sherds were analysed-97 rim and 276 body. All decorative attributes including internal and external treatments were recorded. Profiles of each of the 13 distinct rim forms were drawn in order to account for the variation that exists within each site's assemblage. Slip was recorded on 70 per cent of the total number of sherds recovered, where 37 per cent were light orange (2.5YR 6/6 and 6/8;5YR 6/6 and 6/8), 23 per cent dark orange (2.5YR 5/6 and 5/8;5YR 5/6 and 5/8) and 10 per cent clear orange (5YR 7/6 and 7/8; 7.5YR 7/6 and 7/8). Excluding slips, only 122 (32.7 per cent) sherds displayed evidence of decoration, including channelling, stabbing, fingernail impressions, deep parallel incisions and paint.

Roulette impressions dominated the assemblage, making up approximately 40 per cent of all decorated sherds, with eight distinct roulette patterns identified. The most common roulettes were braided (twines 3, 10) and plaited strip (twines 4, 5) (McIntosh 1995). Ribbing/channelling made up the next most popular motif, comprising 38 per cent of the decorated assemblage. Sherds with deep, parallel incisions accounted for approximately 2 per cent of those decorated, often with dark red or purple paint applied over the incisions. Fingernail impressions ( 12 per cent) and stabbing ( 0.2 per cent) motifs comprised a minor portion of the assemblages.

\section{Discussion}

Currently, the Lakes Region lacks the depth of archaeological research for a concrete ceramic chronology to be developed. A three-phase relative chronology (Recent, Middle and Early) is therefore proposed, largely based on the chronologies of the neighbouring Timbuktu region (McIntosh \& McIntosh 1985; Park 2012). Lebeuf and Paques' (1970) study of Desplagnes's material, as well as the author's review of unpublished material stored at l'Institut Fondamental d'Afrique Noire (IFAN), provide regional context (Figure 9). Although absolute dating of these phases is impossible, the proposed chronology suggests a long occupation of the MLR between the first millennium BC and second millennium $\mathrm{AD}$.

The Early assemblage, between $500 \mathrm{BC}$ and AD 200, was characterised by unslipped, sand-tempered roulette-impressed pottery recovered from Fati3. This variety is common to (C) Antiquity Publications Ltd, 2017 


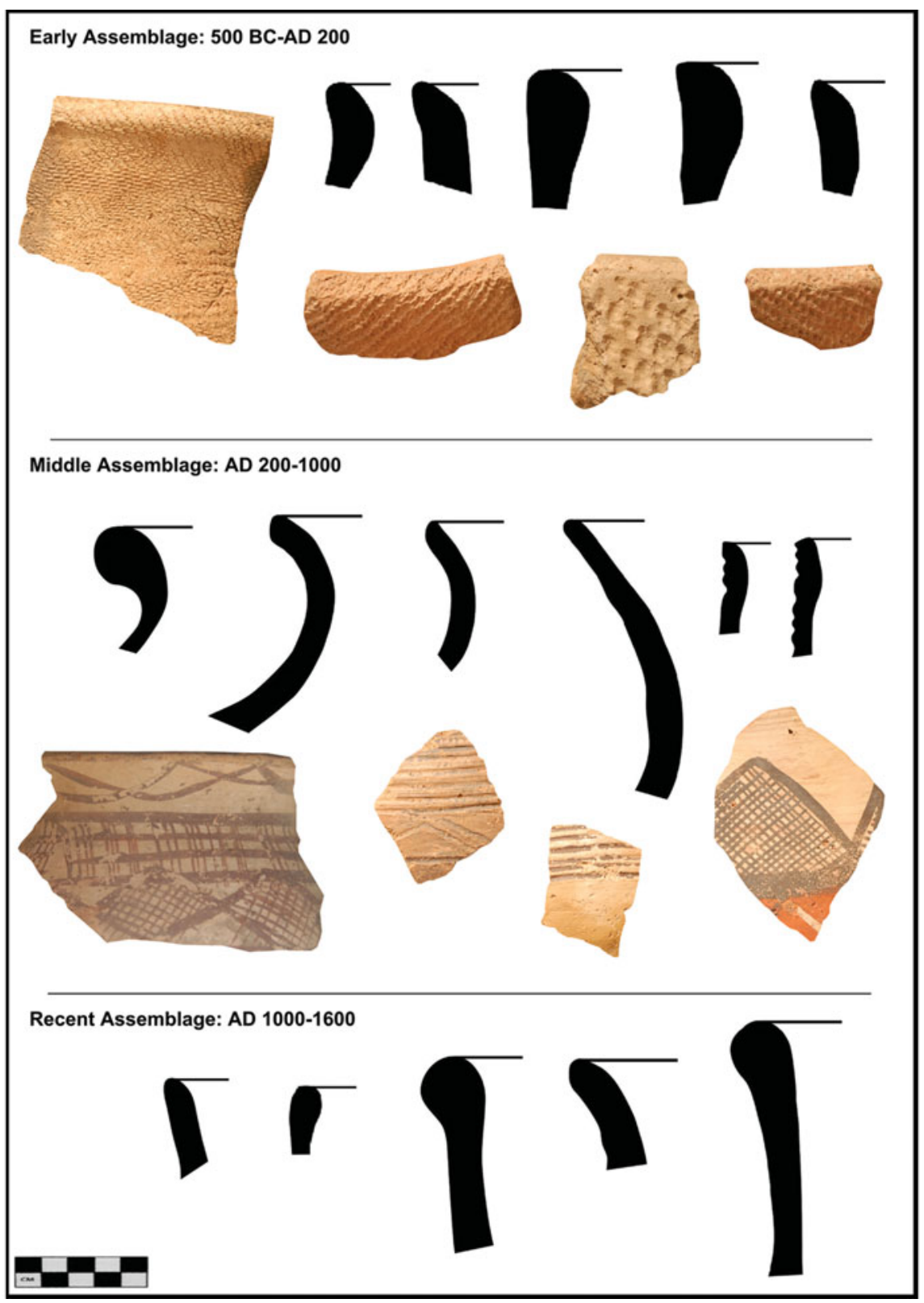

Figure 9. The different rim types associated with different ceramic phases of the MLR.

Late Stone Age/Early Iron Age sites throughout the Sahara and Sahel. Park (2012) found this type in Tombouze phase 1 between 500-400 BC and AD 120-330. Mauny collected several examples from an unnamed site $800 \mathrm{~m}$ east of Goundam (IFAN-SO-52-39) and Tondiarou (IFAN-MAL-55-35). Interestingly, Mauny also excavated several examples from trench 1 at Kouga (IFAN-MAL-55-48), presumably from basal levels. Several thick-rimmed 
vessels with simple roulette impressions along the interior, lip and exterior resemble the Faita Facies identified in the Méma (MacDonald et al. 2003) and the Bandiagara escarpment (Bedaux \& Lange 1983).

The Middle assemblage, from approximately AD 200-1000, was the most diverse and widespread, having been recovered from Fati4, Fati6, Fati7 and Fati9. Everted rim vessels with ribbing/channelling and red slip were the most numerous examples. These vessels were also burnished in small, but significant, numbers. Recovered at both Gao Ancien and Tombouze, these are characteristic of assemblages dating to the second half of the first millennium AD (Insoll 2000; Park 2012). Other burnished wares with geometric comb impressions with a 'checkerboard' pattern of slipped and unslipped areas from the Ghourma Rharous Middle assemblage have been found around Lake Fabuibine (IFAN-MAL-55-394). Triangular or arced comb impressions over red burnished surfaces have been found at Djim-Djim (IFAN-MAL-55-45), El Oualadji and Killi (Lebeuf \& Paques 1970: 28), and in the Gourma-Rharous (McIntosh \& McIntosh 1985). These burnished, comb-impressed sherds are potentially examples of the terminal Middle phase, as they have been elsewhere dated to the turn of the second millennium AD (McIntosh \& McIntosh 1985: 35).

Thin walled $(<20 \mathrm{~mm})$, deeply incised, simple rims were also representative of this assemblage. Outside the Gorbi Valley, Mauny's 1955 expedition recovered examples from the surface of the smaller mound at Kouga (IFAN-MAL-55-55), and two years later, Monod recovered several from the southern edge of Lake Fati (IFAN-SO-58-3). The Timbuktu survey and Tombouze excavations identified these as characteristic of Middle assemblage (AD 500-1500) and phase II (AD 120-330 to 430-640) respectively (McIntosh \& McIntosh 1985; Park 2012).

Although limited in the Gorbi Valley, painted ceramics appear frequently throughout the MLR, having been recovered from Fati6, Djim-Djim (IFAN-MAL-55), El Oualadji, Karegore (IFAN-MAL-55-37), Kouga (IFAN-MAL-55-56), Tondia (IFAN-MAL-55-58), Tondidarou (IFAN-MAL-55-36) and Lake Faguibine (IFAN-MAL-55). This treatment has also been recorded in Tombouze phase II, Dia-Shoma Horizon II (300 BC-AD 300) and later in Jenné-jeno phase III (AD 700-900), Es-Souk periods 2-4 (AD 900-1400), Akumbu Middle assemblage (AD 600-1300), and Gao and Koumbi Saleh (Togola 1993; McIntosh 1995; Berthier 1997; Bedaux et al. 2001; Nixon 2008; Cissé 2011; Park 2012). Within the category of painted wares there are two related yet distinct traditions. The first includes black/dark purple on white, while the second is a polychrome of black, buff, purple and/or white on red. Designs include linear, crosshatching, downward strokes overlaying lateral bands, arced and geometric patterns (including triangular and interlaced waves). In the MLR, paint occurs on diverse vessel forms and on various portions of vessel anatomy. Triangular, linear and arced patterns typically occur on the body, shoulder and neck, while crosshatching or interlaced waves are found on these portions as well as the lip. Polychrome sherds are frequently accompanied by roulette impressions on the body of the vessel, whereas bi-chrome sherds rarely do. The occurrence of these different motifs probably varies chronologically, but the contexts from which many of these examples have been recovered makes identifying this relationship impossible. The late appearance of this treatment at other sites in the region, and its early ubiquity in the MLR and at Timbuktu, may place its origins somewhere along the Niger Bend.

(C) Antiquity Publications Ltd, 2017 
Recent assemblage ceramics were recovered in low numbers from sites Fati6, Fati8 and Fati9. Red-slipped, simple open and everted rims, as well as beaded rims, closely resemble those of the Recent assemblage found in the Timbuktu region defined by McIntosh and McIntosh (1985). Examples include stabbing, fingernail impressions and braided roulettes. Although not recovered during the survey, tobacco pipes have often been associated with Recent assemblage ceramics in other regions, at sites corresponding to modern villages. The limited presence of these ceramics in the Gorbi Valley may be evidence that the region was sparsely inhabited, possibly in decline, during the sixteenth century. For this reason, this phase has been dated to AD 1000-1600.

\section{Conclusions}

The work presented here is preliminary in nature, as follow-up projects were interrupted by regional instability. When viewed in concert with other regional data sets, however, the results of the Gorbi Valley project fill major gaps in our understanding of the cultural history of the Western Sudan.

The general hypothesis for the settlement history of the West African Sahel maintains that northern populations escaped the increasing aridity of the mid-Holocene Sahara by colonising the riparian regions to the south. Exactly when and where these populations came from to settle the MLR is uncertain. Early phase ceramics and the presence of Category 4 sites in the Gorbi Valley suggest that at least some of these populations arrived around the turn of the first millennium BC, during the Chebka/Arriane phases in the Dhar Tichitt. This does not preclude the possibility of earlier populations in the MLR, but evidence for any substantial settlement has yet to be recovered.

Strong connections in material culture during the MLR Middle phase seem to justify the claim that the region was involved in trade with the rest of the Middle Niger and beyond. Its position on the Niger River, downstream from the major population centres of Jenné-jeno and Dia, and upstream from settlements around Timbuktu and Gao, places the MLR at a central point in the "pre-trans-Saharan trade commercial network" of the first millennium AD (McIntosh 2000: 27).

The abandonment of the MLR was probably caused by a combination of political, social and ecological forces. By the mid second millennium AD, high-amplitude climate variations had forced dramatic changes in subsistence patterns across West Africa (McIntosh 2005). This was also a period of dramatic political changes as the Malian Empire was supplanting the (now defunct) Ghana Empire. At this time, a similar pattern of population re-organisation saw the abandonment of Dia Shoma, Jenné-Jeno and Tombouze, in favour of burgeoning early modern urban centres such as Jenné, Dia and Timbuktu (McIntosh 1995; Bedaux et al. 2001; Park 2012).

Many gaps still exist in the chronology of the MLR, a chronology that will eventually elucidate the region's role in the historical development of the Western Sudan. The florescence of sites throughout the first and early second millennia AD, however, places the occupation of the MLR firmly in the age of the Ghana Empire. Although the MLR is situated on the frontier of its traditional boundary, it is unlikely that a region so densely populated was, in fact, marginal to the Empire. Rather than simply a tumuli zone, it is 
far more probable that the MLR functioned as a nexus for trade and exchange, or perhaps something more. As the capital of Ghana probably changed location several times over the Empire's six centuries of dominance, it is not unimaginable that the lakes region was, in fact, home to one of these capitals (McCall \& Stewert 1974; Lange 1994: 285). The presence of large ritual centres such as Tondidarou, the unprecedented Fati6, the density of populations and supra-regional trade connections all demand explanations outside the traditional narrative. What is certain, however, is that future research in the MLR is needed, and will very likely yield further evidence of the significance of the Malian Lakes Region throughout the history of the Western Sudan.

\section{Acknowledgements}

I would like to thank the entire research team and those who gave their guidance and advice throughout this process: Douglas Park, Rod McIntosh, Wade Campbell, Jessamy Doman, Klessigue Sanogo, Ali Ould Sidi, Susan McIntosh and Ibrahima Thiaw. This project would not have been possible without the generous support of the Yale Climate and Energy Institute.

\section{References}

Bedaux, R. \& A.G. Lange. 1983. Tellem: reconnaissance archeologique d'une culture de l'ouest africain au Moyen-Age: la poterie. Journal des Africanistes 53: 5-60. https://doi.org/10.3406/jafr.1983.2037

Bedaux, R., K. MacDonald, A. Person, J. Polet, K. Sanogo, A. Schmidt \& S. SidibÉ. 2001. The Dia archaeological project: rescuing cultural heritage in the inland Niger Delta (Mali). Antiquity 75: 837-76. https://doi.org/10.1017/S0003598X00089419

BerTHIER, S. 1997. Recherches archéologiques sur la capitale de l'empire de Ghana. Étude d'un secteur d'habitat à Kumbi Saleh, Mauritanie. Campagnes II-III-IV-V (1975-1976)-(1980-1981) (British Archaeological Reports international series 680). Oxford: Archaeopress.

Cissé, M. 2011. Archaeological investigations of early trade and urbanism at Gao Saney (Mali). Unpublished PhD dissertation, Rice University.

Connah, G. 2000. African city walls: a neglected source? in D. Anderson \& R. Rathbone (ed.) Africa's urban past: 36-51. Oxford: James Currey.

Coutros, P.R. 2015. Climate change and the particular challenges it poses to the protection of immovable cultural resources in West Africa. Paper presented at Cultural Landscapes \& Heritage Values: Embracing Changes in the Management of Place, University of Massachusetts Amherst, 13-15 May 2015.

Coutros, P.R. \& P.M.J. Douglas. 2015. Coring Lake Fati and settlement archaeology of the Middle Niger Lakes Region. African Archaeological Review 32: 249-66.

https://doi.org/10.1007/s10437-015-9189-4
DembéLÉ, M. 1986. Entre Débo et Faguibine: étude sur la morphologie et la typologie des sites archéologiques d'une région Lacustre au Mali. Unpublished PhD dissertation, École des Hautes Études en Sciences Sociales, Paris.

Dembélé, M. \& M. Raimbault. 1991. Les grandes buttes anthropiques, in M. Raimbault \& K. Sanogo (ed.) Recherche archéologiques au Mali. Prospections et inventaire, fouilles et études analytiques en zone lacustre: 249-58. Paris: ACCT \& Karthala.

Descamps, C. 1979. Contributions à la préhistoire de l'ouest sénégalais. Nyame Akuma 15: 40-41.

Desplagnes, L. 1903. Étude sur les tumuli du Killi, dans la région de Goundam. L'Anthropologie 14: 151-72.

- 1907. Le plateau central nigérien. Une mission archéologique et ethnographique au Soudan français. Paris: Larose.

de Vries, E., A. Makaske, R.J. McIntosh \& J.A. TAinter (ed.). 2005. Geomorphology and human palaeoecology of the Méma, Mali. Wageningen: Alterra.

Fontes, P., D. Mamadi, M. Raimbault \& S. Sidibé. 1985. Prospection archéologique de tumulus et de buttes tumuliformes dans la région des lacs au Mali. Comptes Rendus de l'Académie de Science de Paris, Série III 301: 207-12

Haskell, H., R.J. McIntosh \& S.K. McIntosh. 1986. Archaeological reconnaissance in the region of Dia, Mali. Report prepared for the National Geographic Society, Washington, D.C.

Holl, A. 1985. Background to the Ghana Empire: archaeological investigations on the transition to statehood in the Dhar Tichitt region (Mauritania). Journal of Anthropological Archaeology 4: 73-115. https://doi.org/10.1016/0278-4165(85)90005-4 
-2009 . Coping with uncertainty: Neolithic life in the Dhar Tichitt-Walata, Mauritania, (ca. 4000-2300 BP). Comptes Rendus Geoscience 341: 703-12. https://doi.org/10.1016/j.crte.2009.04.005

Insoll, T. 2000. Urbanism, archaeology and trade: further observations on the Gao Region (Mali). The 1996 fieldseason results (British Archaeology Reports international series 647). Oxford: J. \& E. Hedges.

Jacobberger, P.A. 1988. Drought-related changes to geomorphologic processes in central Mali. Geological Society of America Bulletin 100: 351-61. https://doi.org/10.1130/00167606(1988) $100<0351: D R C T G P>2.3 . C O ; 2$

Lange, D. 1994. From Mande to Songhay: towards a political and ethnic history of medieval Gao. Journal of African History 35: 275-301. https://doi.org/10.1017/S0021853700026438

Lebeuf, A. \& V. Paques. 1970. Archeologie Malienne: Collections Desplagnes. Paris: Musee de l'Homme.

Levtzion, N. 1973. Ancient Ghana and Mali. London: Methuen \& Co.

Levtzion, N. \& J.F.P. Hopkins. 1981. Corpus of early Arabic sources for West African history. Cambridge: Cambridge University Press

MacDonald, K.C. 1994. Socio-economic diversity and the origins of cultural complexity along the Middle Niger (2000 BC to AD 300). Unpublished $\mathrm{PhD}$ dissertation, University of Cambridge.

- 1996. Tichitt-Walata and the Middle Niger: evidence for cultural contact in the second millennium BC, in G. Pwiti \& R. Soper (ed.) Aspects of African archaeology: 429-40. Harare: University of Zimbabwe.

- 1999. Invisible pastoralists: an inquiry into the origins of nomadic pastoralism in the West African Sahel, in C. Gosden \& J. Hather (ed.) Prehistory of food: appetites for change: 333-49. London: Routledge.

MacDonald, K.C., R. Vernet, D.Q. Fuller \& J. Woodhouse. 2003. New light on the Tichitt Tradition: a preliminary report on survey and excavation at Dhar Nema, in P.J. Mitchell, A. Haour \& J. Hobart (ed.) Researching Africa's past: new contributions from British archaeologists: 73-80. Oxford: Oxford University School of Archaeology.

MacDonald, K.C., R. Vernet, M. Martinón-Torres \& D.Q. Fuller. 2009. Dhar Néma: from early agriculture to metallurgy in southeastern Mauritania. Azania 44: 3-48. https://doi.org/10.1080/00671990902811330

Mauny, R. 1961. Tableau géographique de l'ouest africain au Moyen-Age d'après les sources écrites, la tradition et l'archéologie (Memoires de l'Institut Fondamental d'Afrique Noire 61). Dakar: Institut Fondamental d'Afrique Noire.
Martin, V. \& C. Becker. 1974. Répertoire des sites protohistorique du Sénégal et de la Gambie. Kaolack: Ronéotypé.

McCall, D. \& R.F. Stewart. 1974. Reconstructing Early Mande civilizations: Ghana and Mali. Bulletin of the American Schools of Oriental Research (Supplementary Studies) 20: 41-48.

McIntosh, R.J. 1974. Archaeology and mud wall decay in a West African village. World Archaeology 6: 154-70. https://doi.org/10.1080/00438243.1974.9979599

- 1988. The peoples of the Middle Niger. Oxford: Blackwell

- 2000. Clustered cities of the Middle Niger: alternative routes to authority in prehistory, in

D.M. Anderson \& R. Rathbone (ed.) Africa's urban past: 19-35. Oxford: James Currey.

- 2005. Ancient Middle Niger. Urbanism and the self-organizing landscape. New York: Cambridge University Press.

McIntosh, S.K. (ed.). 1995. Excavations at Jenne-jeno, Hambarketolo and Kaniana (Inland Niger Delta, Mali), the 1981 season. Berkeley: University of California Press.

McIntosh, S.K. \& R.J. McIntosh. 1985. Archaeological reconnaissance in the region of Timbuktu, Mali. Unpublished final report to National Geographic.

- 1993. Field survey in the Tumulus Zone of Senegal. African Archaeological Review 11: 73-107.

Munson, P.J. 1971. The Tichitt Tradition: a late prehistoric occupation of the southwestern Sahara. Unpublished $\mathrm{PhD}$ dissertation, University of Illinois at Urbana-Champaign.

Nixon, S. 2008. The archaeology of Early Islamic trans-Saharan trading towns in West Africa: a comparative view and progressive methodology from the entrepôt of Essouk-Tadmekka. Unpublished PhD dissertation, University College London.

PARK, D. 2012 Climate change, human response and the origins of urbanism at prehistoric Timbuktu, Mali. Unpublished PhD dissertation, Yale University.

Raimbault, M. \& K. Sanogo (ed.). 1991. Recherche archéologiques au Mali. Prospections et inventaire, fouilles et études analytiques en zone lacustre. Paris: ACCT and Karthala.

Togola, T. 1993. Archaeological investigations of Iron Age sites in the Méma region, Mali (West Africa). Unpublished PhD dissertation, Rice University.

Received: 11 March 2016; Accepted: 23 September 2016; Revised: 14 September 2016 